\title{
Extralateral Rights to Quartz Veins Granted by the Act of Congress of May 10, 1872
}

\section{$\mathrm{T}$}

HE term "extralateral rights," was coined by Dr. Rossiter W. Raymond, the eminent mining engineer and expert, soon after the passage of the Act, and was used by him to define the right given by the Act, to follow the vein on its departure from the perpendicular, on its descent into the earth, after it has passed through the vertical side lines of the claim.

This right is given by Sec. 2322, U. S. Revised Statutes, which is as follows:

"Sec. 2322: That the locators of all mining locations heretofore made, or which shall hereafter be made, on any mineral, vein, lode, or ledge, situated on the public domain, their heirs, and assigns, where no adverse claim exists at the passage of this Act, so long as they comply with the laws of the United States and the state, territorial, and local regulations, not in conflict with said laws of the United States, governing their possessory title, shall have the exclusive right of possession and enjoyment of all the surface included within the lines of their locations and of all veins, lodes, and ledges, throughout their entire depth, the top or apex of which lies inside of such surface lines extended downward vertically, although such veins, lodes, or ledges may so far depart from a perpendicular in their course downward as to extend outside the vertical side lines of said surface locations; provided, that their right of possession to such outside parts of said veins or ledges shall be confined to such portions thereof as lie between vertical planes drawn downward as aforesaid, through the end lines of their locations, so continued in their own direction that such planes will intersect such exterior parts of said veins or ledges. And provided further, that nothing in this section shall authorize the locator or possessor of a vein or lode which extends, in its downward course, beyond the vertical lines of his claim, to enter upon the surface of a claim owned or possessed by another."

It is provided in Sec. 2320, U. S. Revised Statutes, "that the end lines of each claim shall be parallel to each other."

In order to obtain a full understanding of the provisions of this statute, a few definitions of the words and terms used therein seem necessary. 
"COURSE" or "STRIKE," The "course" or "strike" of a vein is its length horizontally, within the boundaries of the claim.

Some contend that the "course" of a vein applies particularly to the apex thereof, and the "strike" applies to the vein below the apex. The words, however, seem to be interchangeably used by the courts in their decisions.

"DIP." The "dip" of a vein is its departure from the perpendicular, on its descent into the earth.

"APEX." The "apex" of a vein is the entire top of a vein, on its course or strike through a mining claim. It is that part of the entire vein which comes nearest the surface of the earth; where the vein, to use the language of Judge Miller, "seem to have been broken off." It does not mean the highest point on the vein, as the ordinary meaning of the word would indicate, but the entire top of the vein within the boundaries of the claim.

"SIDE LINES." The "side lines" of an ideal mining claim are those which mark the width of the claim on the surface, and run parallel with the vein on its course through the claim.

"END LINES." The "end lines" of an ideal mining claim are those which mark the width of the claim on the surface and run at right angles to the vein on its course through the claim.

An ideal quartz mining claim is a portion of mineral land, 1,500 feet or less in length, along the vein, and 600 feet or less in width.

The following diagram illustrates the surface of such claim, showing the apex and course of the vein, and the side and end lines of the claim:

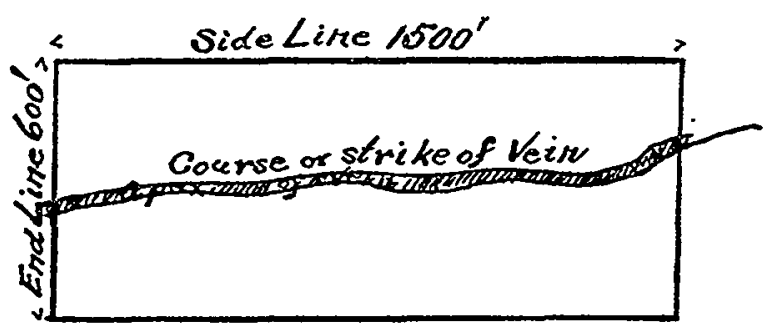

Diagram No. 1.

Ideal Location,-Showing the lines of claim and apex and courses of vein. 
The following diagram illustrates a cross-section of such claim, showing the vertical side lines thereof, and the dip of the vein:

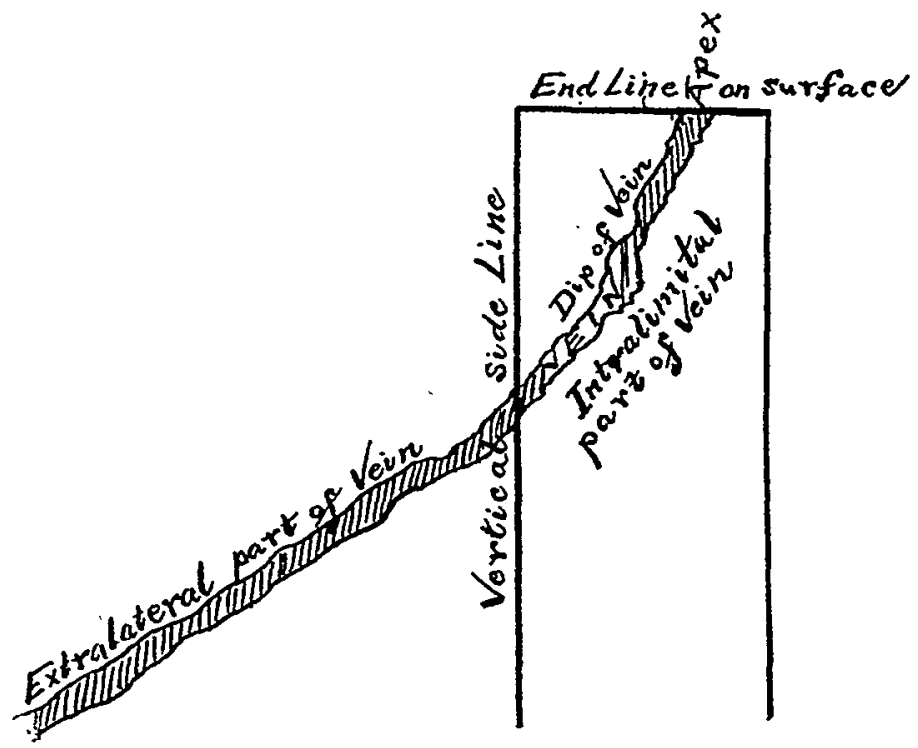

Diagram No. 2.

Cross-section of ideal claim,-Showing dip of vein.

The statute, by its terms, seems only to refer to an ideal location, with the vein on its course or strike passing through its two parallel end lines. The planes of the end lines, dropped downward perpendicularly, and extended in their own direction until they intersect the exterior portions of the vein, bound the extralateral rights on such vein. In actual mining, however, an ideal location is the exception, rather than the rule. Such conditions result from the inability of a locator to determine the actual course or strike of the vein at the time of completing his location. As a matter of fact, the locator of a mining claim usually judges such course or strike from a small portion of the vein disclosed in his place of discovery. It is almost impossible to determine correctly the true course or strike of a vein from such a small exposure. Veins are irregular in their course or strike, and may be found running through the earth in almost every conceivable direction.

The application of the law of extralateral rights, as provided 
for by the above Act, to the varied conditions which have presented themselves, depending on the course or strike of the vein within the surface boundaries of the location, and the form or shape of the location itself, has been the source of prolific litigation in the mining regions of the United States.

In applying this statute, certain well established principles must always be borne in mind, viz:

1. That the basis of extralateral rights is the existence of the apex of the vein within the surface boundaries of the location, dropped downward perpendicularly, and therefore their extent along the vein should always be limited by the extent of the apex within the claim.

This is recognized by the Supreme Court of the United States, in Del Monte Mining Co. v. Last Chance Mining Co. ${ }^{1}$ in which the Court says:

"It must be borne in mind in considering the questions presented, that we are dealing simply with statutory rights. There is no showing of any local customs or rules affecting the rights defined in and prescribed by the statute, and beyond the terms of the statute, courts may not go. They have no power of legislation. They cannot assume the existence of any natural equity, and rule that by reason of such equity a party may follow a vein into the territory of his neighbor and appropriate it to his own use. If cases arise for which Congress has made no provision, the courts cannot supply the defect. Congress having prescribed the conditions upon which extralateral rights may be acquired, a party must bring himself within those conditions, or else be content with simply the mineral beneath the surface of his territory. It is undoubtedly true that the primary thought of the statute is the disposal of the mines and minerals, and in the interpretation of the statute this primary purpose must be recognized and given effect. Hence, whenever a party has acquired the title to the ground within whose surface area is the apex of a vein, with a few or many feet along its course or strike, a right to follow that vein on its dip for the same length ought to be awarded to him if it can be done, and only if it can be done, under any fair and natural construction of the language of the statute. If the surface of the ground was everywhere level, and veins constantly pursued a straight line, there would be little difficulty in legislation to provide for all contingencies; but mineral is apt to be found in mountainous regions where great irregularity of surface exists and the course or strike of the veins is as irregular as

1171 U. S., 55. 
the surface, so that many cases may arise in which statutory provisions will fail to secure to a discoverer of a vein such an amount thereof as equitably it would seem he ought to receive."

2. That in order that extralateral rights exist in any location its end lines must be parallel. ${ }^{2}$

It is not held that the end lines of a mining location must be parallel in order that such location be valid, but only that they must be parallel in order to give extralateral rights to any vein, the apex of which may lie within the surface boundaries of such location. A prospector has the general right to make his location in such shape as he desires, and it will be held valid if he has otherwise complied with the law.

It has also been decided that the parallelism of the end lines

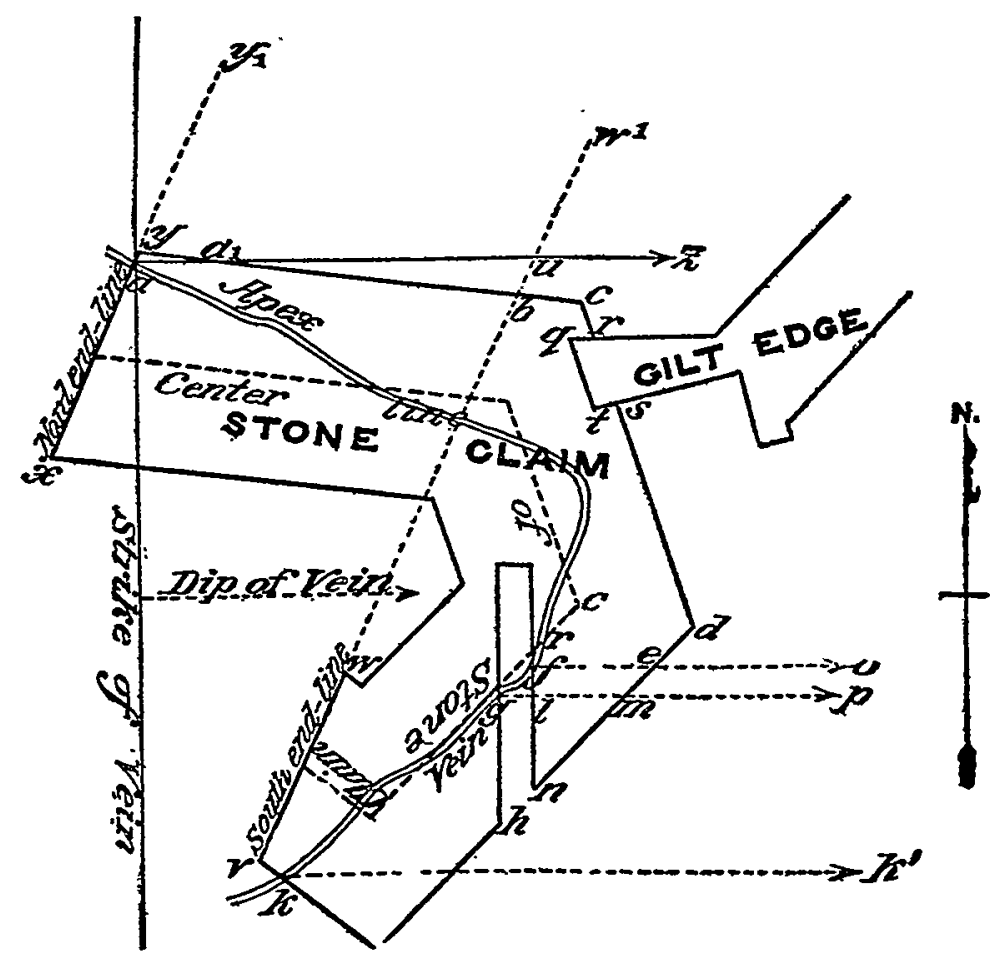

Diagram No. 3.

2Sec. 2320 U. S. Revised Statutes; Iron Silver Mining Co. v. Elgin Mining Co., 118 U. S. 196. 
need not be mathematically accurate; that a substantial parallelism is all that is necessary.

In the case of Iron Silver Mining Co. v. Elgin Mining Co. (supra), the location involved was one of peculiar character. (See Diagram Number 3, on the preceding page.) The lines marked end lines on the location. and which were parallel, were not the lines of the location through which the vein passed on its course and therefore not end lines governing extralateral rights. The particular condition of the apex of the vein was probably occasioned by erosion. The vein lying very nearly horizontal, forces of nature had disentegrated certain portions thereof, by wearing out a gulch, which, of necessity, caused a portion of the apex of the vein to recede from the line which it had originally occupied.

The only method whereby the subject under consideration can be clearly discussed, is by considering the various conditions which may present themselves, and applying the law to each condition.

The statute is clear when applied to an ideal location, and this is the first condition which we shall consider.

1. WHEN THE APEX OF A VEIN ON ITS COURSE PASSES THROUGH BOTH END LINES OF A LOCATION WHICH ARE PARALIEL TO EACH OTHER :

In cases of this character the extralateral rights to such vein are clearly defined by the statute, and are bounded by the vertical planes of the end lines of the claim, extended in their own direction until they intersect the exterior portions of the vein. This condition is sufficiently illustrated in the above diagrams (Nos. 1 and 2), and needs no further comment.

2. WHERE THE APEX OF A VEIN ON ITS COURSE PASSES THROUGH BOTH SIDE LINES OF A LOCATION WHICH ARE PARALLEL TO EACH OTHER:

The Supreme Court of the United States has decided that when this condition appears, the side lines of the location become end lines, for the purpose of determining extralateral rights to the vein, and such rights are bounded on the strike of the vein by vertical planes of such side-end lines extended in 
their own direction until they intersect the exterior parts of the vein. ${ }^{3}$

This condition is clearly disclosed in the following diagram of the claims involved in the Amy Silversmith case (supra):

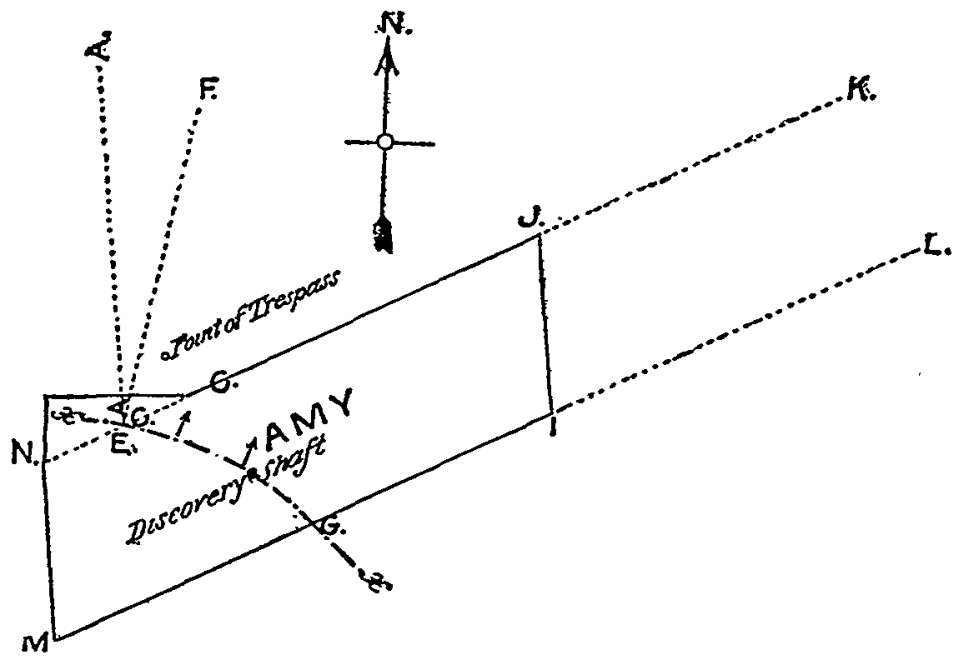

Diagram No. 4.

3. WHERE THE APEX OF A VEIN ON ITS COURSE CROSSES TWO BOUNDARIES OF A LOCATION DIVERGING FROM EACH OTHER IN THE DIRECTION OF THE DIP OF THE VEIN :

In our opinion, no extralateral rights can exist under this condition, because the end lines are not parallel. We must remember that the theory upon which extralateral rights are granted is, that one is entitled to so much of the vein on its dip, as he has apex thereof within his surface boundaries. If the lines of the claim, through which the vein passes on its course, diverge in the direction of the dip, in each foot in depth, the vein would gain length between the planes, and thus include more of the vein extralaterally than there is apex within the location. If the apex of a vein within the boundaries of a lo-

3 Flagstaff Mining Co. v. Tarbett, 98 U. S., 463; King v. Amy Silversmith Co., 152 U. S., 222. 
cation is a certain number of feet in length, equitably the owner of such location should be given the same number of feet on the strike of the vein extralaterally, at any depth, and no more, because he has only so much of the apex of the vein as lies within the boundaries of his claim. The Supreme Court of Montana, in the case of Hicky v. The Anaconda Copper Mining Company, ${ }^{4}$ recognizes this to be the true doctrine. This condition is illustrated by the following diagram:

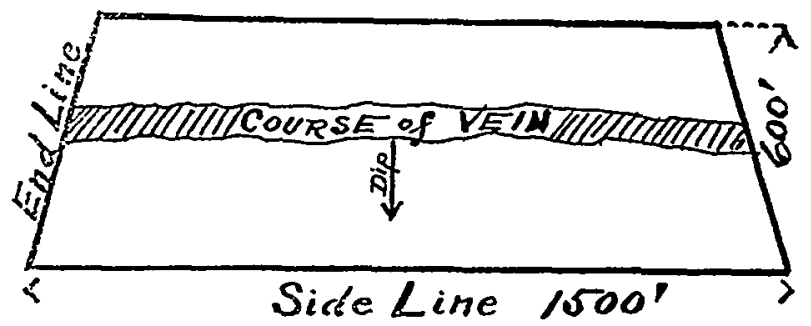

Diagram No. 5.

Vein crossing boundaries of a Location diverging in the direction of the Dip.

4. WHERE THE APEX OF A VEIN CROSSES TWO BOUNDARIES OF A LOCATION WHICH CONVERGE TOWARD EACH OTHER IN THE DIRECTION OF THE DIP OF THE VEIN.

It has been held, in the case of Carson City Gold Mining Co., vs. North Star Mining Co., ${ }^{5}$ that the extralateral rights would exist under this condition, bounded by the vertical planes of the end lines, projected in their own direction, until they should intersect. Judge Lindley, in his valuable work on Mines, announces the same conclusion.

While a strict construction of the statute, and a strict application of the doctrine of the "Horse Shoe Case" would preclude extralateral rights under a condition of this character, we can

433 Mont., 46.

586 Fed., 658.

6 Iron Silver Mining Co. v. Elgin Mining Co., 118 U. S., 196. 
see no reason why such rights should not attach. This condition is illustrated in the following diagram:

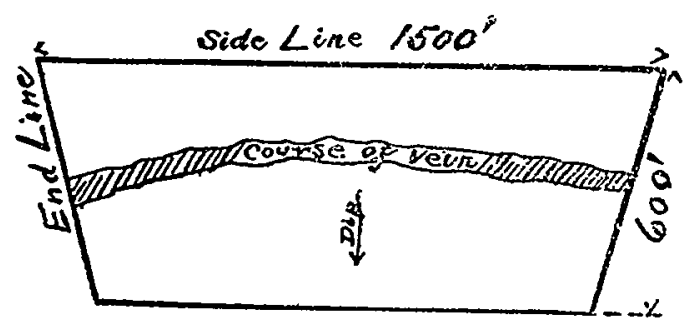

Diagram No. 6.

Vein crossing boundaries converging in the direction of the Dip.

5. WHERE THE APEX OF A VEIN ON ITS COURSE CROSSES ONE SIDE LINE AND ONE END LINE OF A LOCATION.

Under the Act of Congress, the doctrine has been established by the Supreme Court of the United States, that the extralateral

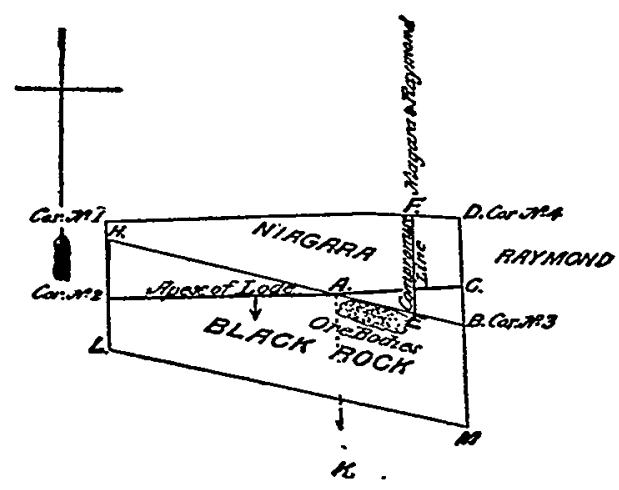

Diagram No. 7.

rights on a vein under this condition, would be bounded by a plane dropped downward perpendicularly through the end line of the claim, through which the vein passes on its course, and a plane parallel therewith, dropped downward perpendicularly through the point where the vein departs from the surface boundaries of the location through the side line. These 
planes extended in their own direction, would bound the extralateral rights on such vein under such condition. "This condition is shown by diagram No. 7 , on the page preceding, illustrative of the case last above cited.

\section{WHERE THE APEX OF A VEIN ON ITS COURSE ENTERS AND DEPARTS FROM THE CLAIM THROUGH THE SAME BOUNDARY LINE.}

The Supreme Court of Colorado has held that under such condition, no extralateral rights exist. ${ }^{8}$

The United States Court of Appeals for the Ninth Circuit, however, holds that extralateral rights to such veins do exist.9

The extent of the extralateral rights on a vein under the conditions presented to the Court of Appeals in this case, presented a very interesting question. The vein in controversy was a wide one, and entered and departed from the St. Louis claim, at an angle, through the same side line thereof. To which location did the extralateral rights to the vein, at the place of crossing this line belong? At the place of departure from the St. Louis claim, the apex of the vein was conceded to be 25 feet in width, measured along the boundary line through which it departed. The St. Louis claim was conceded to be the prior location, and the owner thereof claimed that it was, therefore, entitled to all extralateral rights on the vein, so long as any portion of its apex remained within the boundaries of such claim. The owner of the $9 \mathrm{Hr}$. claim, into which it dipped, and into which the apex entered on its departure from the St. Louis claim, insisted that the St. Louis claim was only entitled to extralateral rights to the vein so long as its entire apex remained within the boundary of the St. Louis claim.

The Court of Appeals, however, said:

"The only deduction which can be made from the foregoing rules is that, inasmuch as neither statute nor authority permits a division of the crossing portion of the vein, and the weight of authority favors the senior locator, the entire vein must be considered as apexing on the senior location until it has wholly passed beyond its side line."

7 Del Monte Mining Co. v. Last Chance Mining Co., 171 U. S., 55; Clarke v. Fitzgerald, 171 U. S., 92.

8 Catron v. Olds, 23 Colo, 433.

'St. Louis Mining Co. v. Montana Mining Co., 104 Fed., 664. 
This condition is illustrated by the following diagram, which discloses the properties which were in conflict in the St. Louis case :

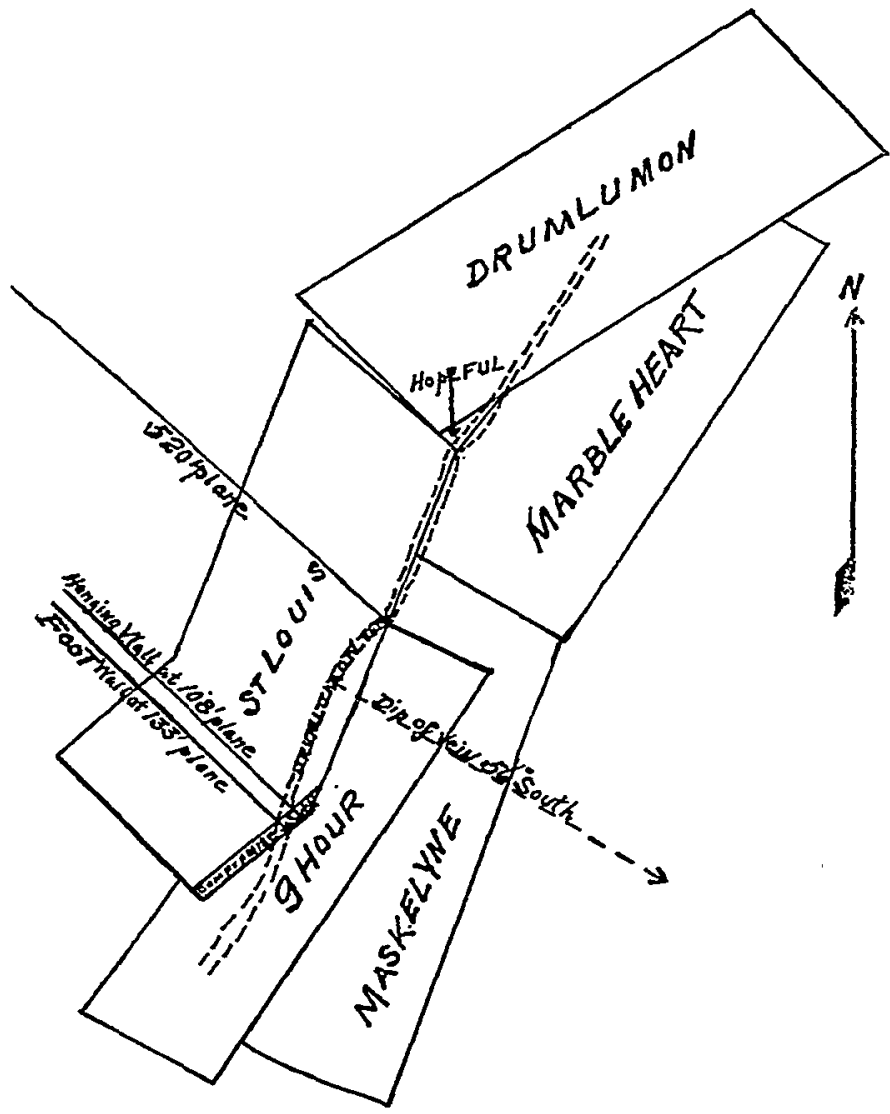

Diagram No. 8.

Showing course of the Drumlumon vein.

While the Supreme Court of the United States has never directly passed upon this condition, it has frequently, since the decision of the Appellate Court (supra), cited the same on other points and, when we consider, that the Supreme Court of the United States, on a writ of certiorari, reviewed a judgment which was obtained by the St. Louis Mining Company 
on the theory established by the case above cited, and made no reference to the law as there established, we feel justified in the conclusion that the Supreme Court affirmed the same upon a later appeal of the same case. The Court of Appeals said:

"We are therefore of the opinion that the right of the St. Louis Mining Company to extralateral rights in the Drum Lummon to the extent that it apexes within the St. Louis Mining Company's claim, has been previously determined by this court, and that this determination has been affirmed by the Supreme Court of the United States (204 U. S., 204), and that such has become the law of the case." 10

True, the vein in question in this case was an incidental or secondary vein, but in our judgment that makes no difference, because the statute provides that the owner of a location is entitled to all veins which apex within its surface boundaries, even though they depart from the claim on their descent into the earth. The doctrine announced by the above case gives to the locator precisely the amount of the vein extralaterally, to which he is entitled by reason of having the apex thereof within its surface boundaries.

7. WHERE THE APEX OF A VEIN ON ITS COURSE IS SPLIT BY A BOUNDARY LINE OF A LOCATION, OR WHERE THE VEIN IS WIDER THAN THE LOCATION ITSELF.

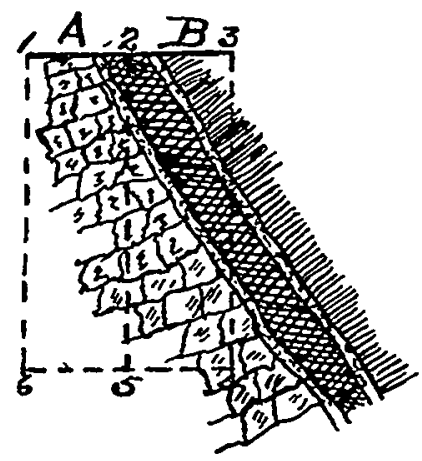

Diagram No. 9.

10183 Fed., 61. 
Under these conditions the Supreme Court of the United States has decided that the prior location is entitled to the extralateral rights of the entire vein.11

This conclusion was reached by the Supreme Court, for the reason that the statute evidently did not intend that extralateral rights to any vein should be divided, and therefore gave the extralateral rights to the entire vein to the prior locator.

Diagram No. 9, on page 347, used by Dr. Raymond, and copied from "Lindley on Mines," illustrates the condition discussed.

8. WHERE THE APEX OF AN ORIGINAL VEIN ON ITS COURSE ENTERS THROUGH ONE IINE OF A LOCATION, AND CEASES BEFORE IT REACHES ANY OTHER BOUNDARY; and

\section{WHERE THE APEX OF AN ORIGINAL VEIN ON ITS COURSE DOES NOT REACH OR PASS THROUGH ANY SURFACE BOUNDARY.}

Under both of these conditions the extralateral rights of the vein would be limited by planes dropped downward perpendicularly through the end lines of the claim.

It has been frequently stated that the boundary planes of the extralateral rights, under condition 8 , would be the plane of the end line through which the vein passed, and another plane parallel thereto, drawn through the location at the point where the vein ceases on its course. If the vein. on its course, ceases at any point within the surface boundaries of the location, there is no occasion for bounding the extralateral rights by such plane, because such rights are limited by the end line planes of the location, and if there is no vein there are no extralateral rights.

The same is true with condition 9, with the exception that in such instance it is claimed the extralateral rights would be bounded by the planes parallel to the end lines of the claim through which the vein would pass if projected in its own direction, dropped perpendicularly through the claim at the points where the vein ceases. There can be no occasion to bound

11 Argentine Mining Co. v. Terrible Mining Co., 122 U. S., 478; Lawson v. U. S. Mining Co., 207 U. S. 1; see also: Empire State Co. v. Bunker Hill Mining Co., 114 Fed. 417. 
such extralateral rights; they are limited by the planes of the end lines, either actual or constructive, as above stated.

We cannot conceive how any case should possibly arise, calling for the Court's construction of the Statutes, which would require or justify a holding that the extralateral rights would be bounded by planes dropped through the point of the discontinuance of the vein.

10. WHERE A VEIN PASSES THROUGH BOTH END

LINES OF A LOCATION BUT IN ITS COURSE DEPARTS FROM THE CLAIM THROUGH A SIDE, LINE, AND RE-ENTERS THE CLAIM THROUGH THE SAME SIDE LINE.

This condition may be illustrated by the following diagram:

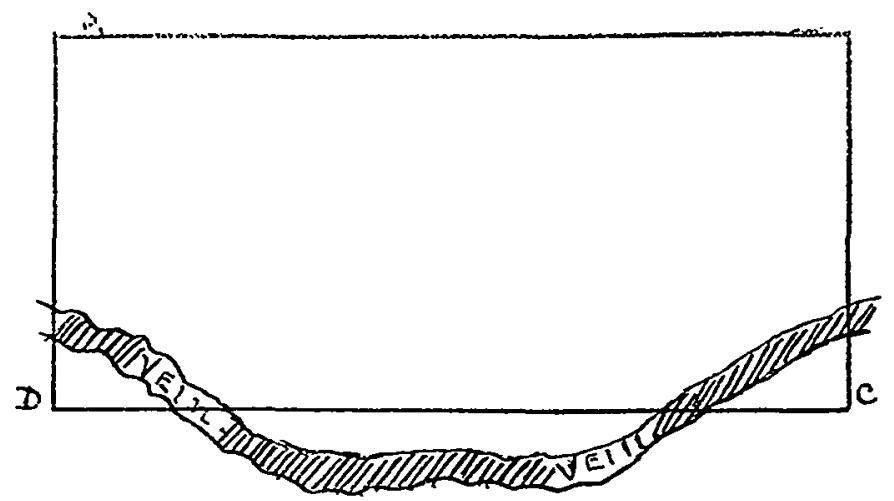

Diagram No. $9 \mathrm{~s} / 2$.

We find no reported case upon this condition, although Judge Ross in the case of Doe v. Waterloo, ${ }^{12}$ refers to one of the same character, and Judge Lindley in his valuable work on Mines refers to a case of Sims v. Garden M. \& M. Co. as having been decided by Judge A. $H$. de France in one of the trial

1282 Fed., 45. 
courts of Colorado, in which this exact condition presented itself. ${ }^{13}$

By applying the principles hereinabove announced with reference to other conditions, no trouble will be encountered in determining the law upon this situation.

Extralateral rights as above stated are based upon the apex of a vein, being situated within the vertical boundaries of a claim. A claim is entitled to the same length along such vein, extralaterally, as it has length of apex within its vertical boundaries and no more; when a vein passes through an end line and departs from a side line of a claim the extralateral rights therein are bounded by the plane of this end line through which the vein passes, and a plane parallel thereto dropped through the claim at the point where it passes through the side line.

\section{EXTRALATERAL RIGHTS ON INCIDENTAL OR SECONDARY VEINS.}

It must be remembered that the statute gives extralateral rights on all veins which have their apices or tops within the vertical boundaries of the location.

It frequently occurs that the apex of more than one vein exists within such vertical boundaries. The vein upon which the location is based, bears the designation of "original" or "discovery" vein; other veins are called "incidental" or "secondary" veins. This nomenclature is immaterial, inasmuch as the rights given by the statute apply to all veins apexing within the vertical boundaries of the location. Any designation is, therefore, only for the purpose of identification, and to distingnish the different veins from each other. Of course, the vein upon which the location is based, should be, and is the vein which determines the planes limiting the extralateral rights to all veins apexing within the location. In fact, the Supreme Court of the United States has said: "Appellant's right upon the Contact (a secondary and incidental) vein is given by this statute (Sec. 2322, U. S. Revised Statutes). What limits the right extralaterally? The statute says vertical planes drawn downward through the end lines of the location. What end lines? Those of, and as determined by the original location and

13 Lindley on Mines, 2d Ed., Sec. 591. 
lode, the Circuit Court of Appeals decided. Those determined by the direction of the newly discovered lodes, regardless of whether they were originally intended as end lines or side lines, the appellant, as we have seen, contends. The Court of Appeals was right. Against the contention of appellant, the letter and spirit of the statutes oppose, and against it, the decisions of this court also oppose." 14

The following diagram illustrates the controversy involved in this case :

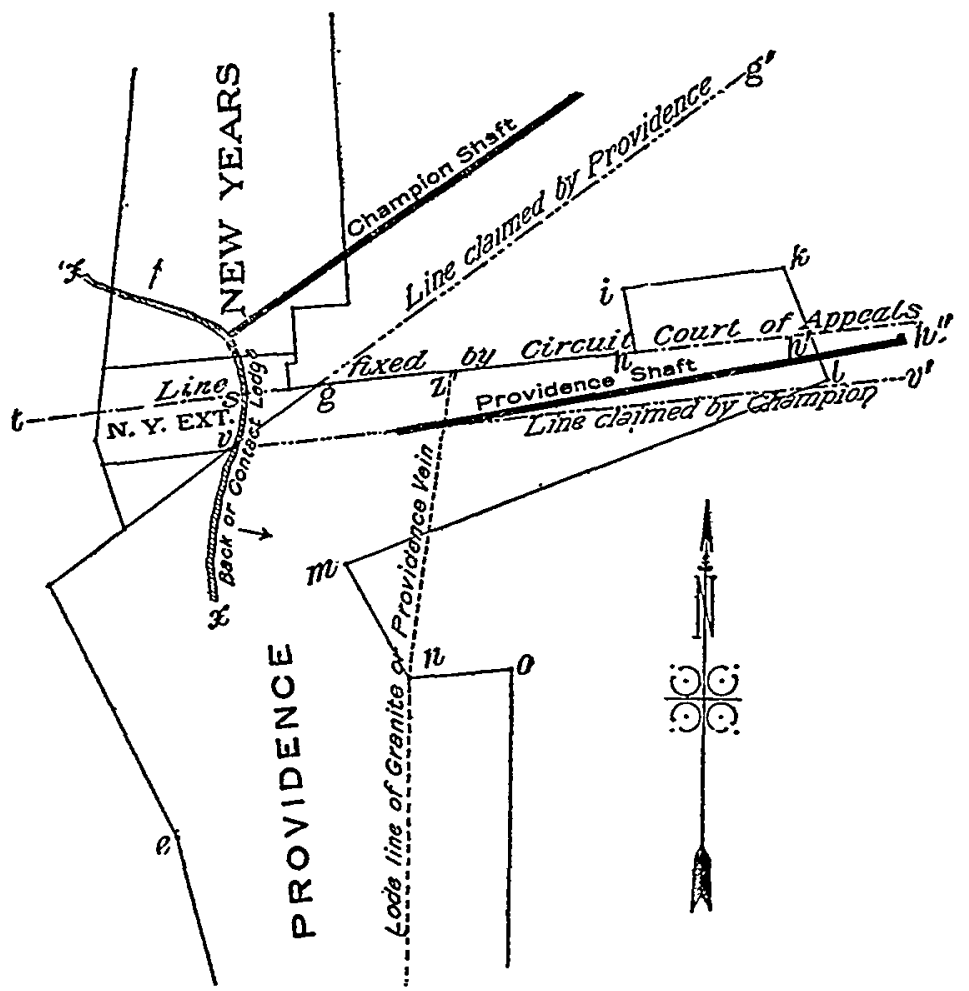

Diagram No. 10.

The effect of the opinion of the Appellate Court in this

14 Walrath v. Champion Mining Co., 171 U. S., 293. 
case, ${ }^{15}$ and of the Supreme Court (supra), at first blush would seem to give a claim a greater length on the strike of a secondary or incidental vein, extralaterally, than it has length of the apex thereof, within its surface boundaries. If we apply the rule strictly as therein announced, i. e., that the end line planes of a location, as fixed by the original vein, for determining extralateral rights thereon, bound the extralateral rights to all incidental or secondary veins, the absurd result would follow, that if the original vein on its course ran through two parallel end lines of an ideal location, such location would have extralateral rights on all secondary or incidental veins apexing therein, for the full length of the claim, while the length of the apex of such secondary vein, within the claim, might be only a few feet. We cannot impugn such an absurd conclusion to the greatest court in the world. It is very apparent from the opinion, that such conclusion never entered the minds of the judges of that court. The Del Monte case was decided on the same day, and in that case, the court announced the rule, that a greater length along the strike of a vein extralaterally, than the length of the apex within the location, should not be given. The court, in the Walrath case, cites and quotes from the Del Monte case, and relies upon it as as authority.

The Supreme Court, however, was somewhat careless in the use of certain language of the opinion. Had it carefully confined itself to applying the principle announced in the language above quoted and held that the end line planes would always "limit" the extralateral rights, much confusion might have been avoided.

Judge Lindley, the eminent author on "Mines and Mining," (one of the attorneys employed in the Walrath case) fully explains the conditions involved, and concludes that the court did not mean what has been attributed to it.

Much criticism in this case has been indulged in by mining lawyers, and we can but believe that if the opportunity is ever afforded, the Supreme Court will clear up the erroneous inferences which have been drawn from that opinion.

The Supreme Court of Colorado, in the case of Ajax Mining Co. vs. Hilkey, ${ }^{16}$ in our judgment, announces the true 
rule relative to extralateral rights on incidental or secondary veins, in patented quartz claims, although there may be some doubt as to whether the law announced by that court, was correctly applied to the facts as they appeared in the litigation, under the decisions of King vs. Amy Silversmith Co., ${ }^{17}$ and Cosmopolitan Mining Co. vs. Foote. ${ }^{18}$

The following diagram describes the veins and locations involved in the Colorado case.

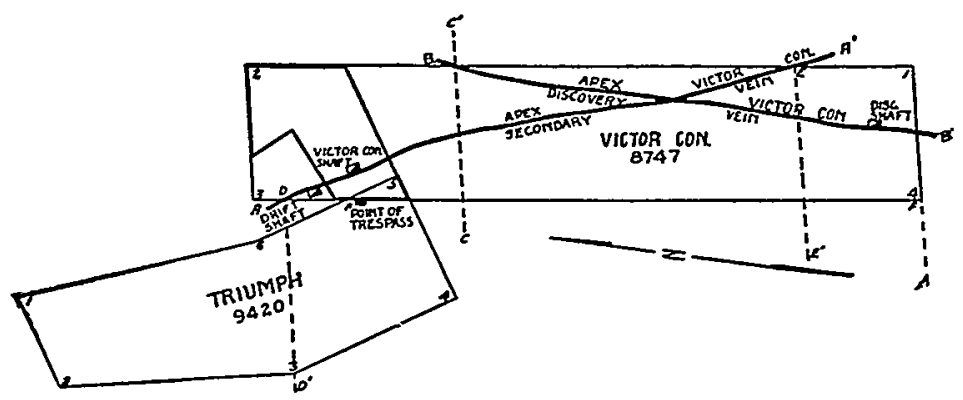

Diagram No. 11.

The Court, in its opinion, did not rely upon any inference which might have been drawn from the Walrath case, but announced the rule that, when the original and incidental veins do not fully pass through the same segments of a location, such fact is no reason for denying the location extralateral rights on both such original and incidental veins, to the full extent each vein apexes within the location. The Court said:

"The end lines constitute a barrier, beyond which a locator cannot follow a vein on its strike, whether it be a discovery or secondary vein; and they also limit the bounding planes within which his extralateral rights are to be exercised in following such vein on its dip. In exercising such extralateral rights the locator cannot, in any case, pursue the vein on its dip beyond the bounding planes drawn through the end lines; but, as we have said, appellant is content to be restricted in the exercise of such rights in the secondary vein, to planes drawn parallel to the end lines, and passing, the one through the claim at the point where the vein enters, and the other where

17152 U. S., 222.

18101 Fed., 518. 
it departs from, the surface line of the location. The extent of the right depends upon the length of the apex, and the extralateral rights are measured not necessarily by the end lines and not only so when the vein passes across both end lines-but by bounding the planes drawn parallel to the end lines passing through the claim at the points where it enters into and departs from the same. It would seem, therefore, necessarily to follow that the extralateral right depends, inter alia. upon the extent of the apex within the surface lines, and while the end lines of the claim as fixed by the location are the end lines of all veins apexing within its exterior boundaries, the planes which bound such rights of different veins may be as different as the extent of their respective apices, though all such planes must be drawn vertically downward parallel with the end lines. It makes no difference in what portion of the patented claim the apex is. Its extralateral rights, under this rule, can easily be ascertained. The apex of a secondary vein need not be in the same portion of the claim as is the apex of the discovery vein. The statute does not say so."

In delivering its final conclusions upon the propositions involved, it further states:

"Our conclusion is that for all veins, both discovery and secondary, of a patented claim, the owner has extralateral rights, at least for so much thereof as apex within the surface lines; that such rights as to secondary veins are not confined to such veins as apex within the same segment of the claim in which the apex of the discovery vein exists; and while the end lines of the location, as fixed and described in the patent, are the end lines of all veins apexing within the surface boundaries, and may constitute the bounding planes for such extralateral rights, and in no case can the locator pursue the vein on its dip outside the surface lines beyond such planes continued in their own direction until they intersect such veins, yet these bounding planes, which in all cases must be drawn parallel to the end lines, need not be co-incident."

There can be no doubt but that the end line planes (as fixed by the position of the original vein), for the purpose of defining extralateral rights thereto, limit the extralateral rights to all veins apexing within the location, beyond which extralateral rights cannot exist. It is equally trie that a locator can have but one set of end lines for all purposes. However, we cannot perceive how these principles are impinged upon by dropping an imaginary plane parallel to the end lines of the claim, through the point where an incidental or secondary vein enters or departs from the location, and extending it in its own direction for the purpose of bounding the extralateral rights up- 
on such vein. The Supreme Court of the United States has found no difficullty in applying such planes to cases where the apex of the original vein enters the location through an end line, and departs therefrom through a side line. ${ }^{19}$

It is clear, however, that when the secondary or incidental vein, on its course, crosses both side lines of a location, as fixed by the course of the original or discovery vein, no extralateral rights can attach to such secondary or incidental vein, if it is impossible to apply either of the limiting planes of the end lines in planes parallel thereto, as applicable to the original vein, to such secondary vein for the purpose of bounding the extent of such rights. ${ }^{20}$

\section{EXTRALATERAL RIGHTS MAY BE CURTAILED OR INTERRUPTED BY CONFLICT ON THE DIP OF THE VEIN WITH RIGHTS UNDER A PRIOR LOCATION.}

Thus when two or more locations, made on the same vein, are so situated with reference to each other as to cause a conflict on the dip of the vein. This is illustrated by the following diagram of the conflict of rights in the famous "Stemwinder case" cited in the note.

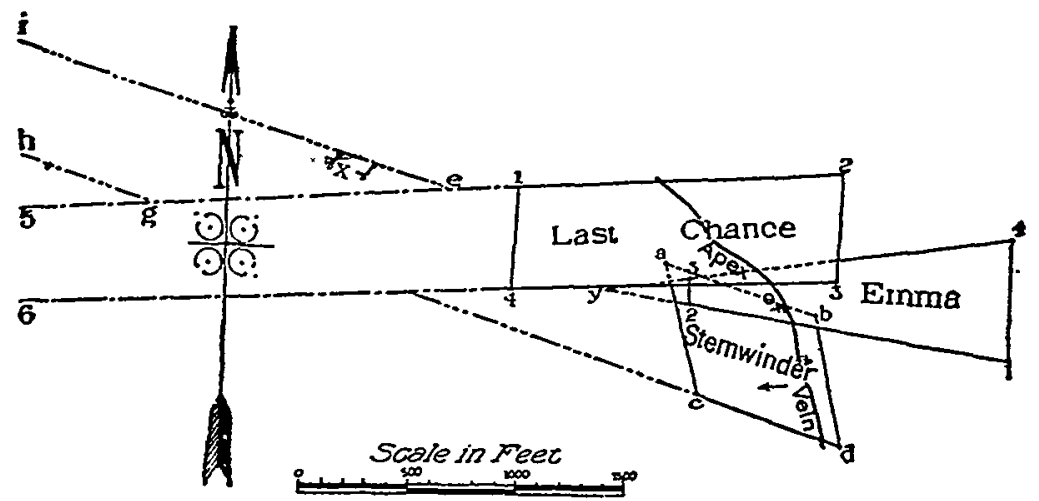

Diagram No. 12.

${ }^{19}$ Del Monte v. Last Chance Mining Co. (supra); Clark v. Fitzgerald (supra).

20 Cosmopolitan Mining Co. v. Foote, 101 Fed., 518. 
In such instances the extralateral rights belonging to the prior valid location take that portion of the vein in conflict. ${ }^{21}$

The extralateral rights of the junior location, however, again attach to the vein beyond the conflict. ${ }^{22}$

One entitled to extralateral rights on a vein may convey a certain section of the vein on its dip, which will be carved out of his extralateral rights, leaving such rights beyond unimpaired. $^{23}$

\section{RIGHT TO FOLLOW THE VEIN EXTRALATERALLY, WHERE THE VEIN ON ITS DIP ENTERS THE VERTICAL BOUNDARIES OF A PRIOR GOVERNMENTAL GRANT.}

Whether the owner of a legally located quartz claim, having within its surface boundaries the apex of a vein, has the right to follow and mine such vein extralaterally after it enters the vertical boundaries of a tract of land which has been theretofore patented by the Government as agricultural land, is a question which has never been decided by the Supreme Court of the United States, to our knowledge.

Judge Sawyer, while sitting as Judge of the Circuit Court of the United States in the Ninth Circuit, has, however, decided that such vein could not be followed by the owner of such claim beyond the point where on its dip it enters the vertical boundaries of such prior agricultural grant.24

With this conclusion, Judge Lindley, the eminent author on mining law, does not agree, but is of the opinion that all of the acts of Congress relative to the disposal of the public domain should be construed as being in pari materia, and that when so construed all veins which, on their dip, enter the vertical boundaries of an agricultural grant, are reserved therefrom

21 Tyler v. Sweeney, 79 Fed., 277; Tyler v. Last Chance Mining Co., 71 Fed., 848.

22 Empire State, etc., Mining Co. v. Bunker Hill, etc. Mining Co., 121 Fed. 937.; see also: Empire State, etc. Mining Co. v. Bunker Hill, etc. Mining Co., $114 \mathrm{Fed.,417}$; Bunker Hill, etc., Mining Co v. Empire State, etc. Mining Co., 109 Fed. 538; Bunker Hill, etc. Mining Co. v. Empire State, etc. Mining Co., 134 Fed. 268; Davis v. Shepherd, 31 Col., 141.

28 Montana Mining Co. Ltd., v. St. Louis, etc. Mining Co., 204 U. S., 204.

24 Amador Mining Co. v. S. S. H. Mining Co., 36 Fed., 668. 
by operation of law, irrespective of whether such grant was prior or subsequent in time of right to quartz location.

When such eminent authorities hold diametrically opposing views upon any proposition of mining law, which has never been decided by the Supreme Court of the United States, one can only express an opinion as to which is correct. In our judgment the conclusions of Judge Lindley are correct and will be sustained if the question ever comes before the Supreme Court of the United States.

However, if the vein on its dip enters a prior patented mining claim it may be followed because it is always expressly reserved by the statute and by the patent itself. ${ }^{25}$

\section{UNAPPROPRIATED RIGHTS TO A VEIN ON THE DIP.}

Where the apex of a vein is entirely within located claims, which have end lines diverging in the direction of the dip, so that a portion of the vein on its dip is unoccupied and unappropriated, we find three lines of decisions:

(1) That such portion of the vein may be divided between the adjoining locations which own the entire apex of the vein. ${ }^{26}$

(2) That the owner of the surface under which the unappropriated part of the vein lies, owns it under his commonlaw rights, ${ }^{27}$ And

(3) That such unappropriated part of the vein may be located and acquired by any qualified locator, who makes a location, the surface boundaries of which include the apex of that part of the vein, even though such locations are made by placing the stakes and marking the boundaries thereof on other locations, provided such location is made for the purpose of covering such unappropriated extralateral rights. ${ }^{28}$

There can be no question but that the decision in $75 \mathrm{Cal} ., 78$,

25 Blake v. Butte Silver Mining Co., 2 Utah, 54, Colorado, etc. Co. v. Turck, 70 Fed., 294; Clark v. Fitzgerald, 171 U. S., 92.

26 Champion Mining Co. v. Consolidated Wyoming Gold Mining Co., $75 \mathrm{Cal} ., 78$.

${ }^{27}$ State v. Second Judicial District Court, 25 Montana, 504; Parrott Silver, etc. Co. v. Heinze, 25 Montana, 139; 87 Am. St. Rep. 386; 53 I. R. A., 491

${ }_{28} \mathrm{Del}$ Monte Mining, etc. Co. v. Irast Chance Mining Co., $171 \mathrm{U}$. S. 55; see also: Bunker Hill, etc. Mining Co. v. Empire State-Idaho Mining etc. Co., 134 Fed. 268; Bunker Hill, etc. Mining Co. v. Empire StateIdaho Mining, etc. Co., 109 Fed., 538. 
supra, is without support, either on principle or authority. Such decision would give to each of the adjacent owners rights to a vein extralaterally, after it had passed out of the end line planes of the location. This would be in direct violation of the Mining Act and the decisions of the Supreme Court of the United States.

As to the second class of cases $^{29}$ while the opinions of the Court are well reasoned, we cannot conceive how the conclusion of the Court arrived at can be sustained until the Supreme Court of the United States recedes from the doctrine foreshadowed by Judge Brewer in the Del Monte case, supra. The Supreme Court of the United States is the final arbiter upon all questions and rights growing out of the Mineral Acts of Congress.

\section{BOUNDARIES OF EXTRALATERAL RIGHTS BY}

\section{AGREEMENT}

The boundaries of extralateral rights on any vein may be fixed by agreement of the parties, either by conveyance or contract. $^{30}$

It would seem that the law of extralateral rights under the Statute of 1872 is practically settled. It is fully settled when applicable to conditions which have presented themselves for adjudication, yet the forms of mining locations may be so variant, and the position of veins within the vertical boundaries thereof so strange and peculiar, that many complications, now unthought of, may present themselves for adjudication, but if the courts continue to bear in mind the purpose and intent of the Mineral Act, and the principles already settled, no serious difficulty will arise in determining the law applicable to any complications.

San Francisco, California.

JNO. B. CLAYBERG.

2925 Montana, 504; 25 Montana, 139, supra.

30 Montana Ore Purchasing Co. v. Boston, etc. Co., 27 Mont., 536; Butte, etc. Mining Co. v. Montana Ore Purchasing Co., 27 Mont., 152; Kennedy Mining Co v. Argonaut Mining Co., 189 U. S., 1; Eureka Consolidated Mining Co. v. Richmond Mining Co., Fed Cases, No. 4548. 